Vol. 2, No. 1, June 2021

DOI: https://doi.org/10.18196/ijiep.v2i1.11851

\title{
Social Factor Effects on Linguistic Performance, Emotional and Spiritual Intelligence
}

\author{
Kasmil S. Abdulwahid \\ Mindanao State University - Tawi-Tawi College of Technology and Oceanography \\ Corresponding email: sandrakasmil@yahoo.com
}

ARTICLE INFO

Article history

Received, 31/05/2021

Revised, 17/06/2021

Accepted, 18/06/2021

Keywords

Social Factors

Linguistic Performance,

Emotional Intelligence,

Spiritual Intelligence

\begin{abstract}
The main focus of this study was to determine the significant effect of social factors on linguistic performance, emotional and spiritual intelligence. The descriptive-quantitative method of research was used in the study. There were 110 students included as respondents that were selected through simple random sampling. The linguistic performance test, USM Emotional Quotient Inventory, and Spiritual Intelligence Self-Report Inventory served as instruments to gather data from the respondents. The data were analyzed through the use of $t$-test, ANOVA, and post-hoc. Based on the careful analysis, social factors affected students' linguistic performance, emotional and spiritual intelligence. The findings are summarized into the following: 1) There was a significant difference among the respondents' linguistic performance on students' family religiosity, involvement in the social group, and students' madrasah experience, 2) There was a significant difference in their emotional intelligence as far as students' family educational attainment, income, and students' madrasah experience, and 3) There was a significant difference on students' spiritual intelligence on their involvement in the social group.
\end{abstract}

This is an open access article under the CC-BY-SA license.

\section{Citation:}

Abdulwahid, K. S. (2021). Social factor effects on linguistic performance, emotional and spiritual intelligence. International Journal of Islamic Educational Psychology, 2(1), 15-35. DOI: https://doi.org/10.18196/ijiep.v2i1.11851 
Abdulwahid | Social Factor Effects on Linguistic Performance, Emotional and Spiritual Intelligence

\section{INTRODUCTION}

Parents are investing a lot of their money for their children's good education, but whether or not their children are learning inside the classroom or school is crucial for the teachers and the school administrators. Intelligence contributes to students learning. Still, there is no clear basis as to either students' intellectual, emotional or spiritual intelligence drastically affects learning or does have a significant relationship to their knowledge (Pant \& Srivastava, 2019). This issue is a serious question that needs further investigation. In aiming for holistic excellence and for the students to succeed in life, intellectual intelligence is insufficient; certainly, teachers must develop students' emotional and spiritual aspects (Tüzer et al., 2020). The early beliefs and studies claimed that intellectual intelligence or the cognitive capacities of students is the best precursor in determining a student's achievement and performance inside the classroom. However, with the latest findings on performance and achievement, emotional and spiritual intelligence were somehow found to affect student's performance. Factors that would likely affect students' performance are social factors.

In the Arabic language, intelligence can be translated into 'aql. Allah (SWT), the Creator, gave human beings' aql and becomes one of their prized possessions and blessings from the creator (Fadhil \& Sebgag, 2021). Those who do not possess 'aql or are deficient in it can be considered useless citizens in the community. Life will be senseless and meaningless for them and what is worst is that they could become a liability in the family, society, and the nation in general. Students should possess a higher level of intelligence, whether cognitive, emotional, or spiritual intelligence, so much to contribute something to their community and could even become an asset to the community and country as a whole.

People generally should use their different bits of intelligence from time to time because, whether they like it or not, a time would come wherein their intelligence could diminish if not completely disappear, such as old age and senility. Many Psychologists define and explain intelligence differently. Terman and Thorndike do differ as far as their definition of intelligence (Sternberg, 2020). For Terman, intelligence is the ability to abstract thinking, while Thorndike claimed that it is one's ability to respond to any query appropriately (Encyclopedia Britannica).

Intelligence is a general term that means the ability to think, reason, execute or put into action the systematic processes and the simultaneous functioning of the human mind, heart, and soul. It can be considered the human ability to absorb, analyze, and react to the truth and reality (Suud et al., 2019). Also, it is a combination of complex factors triggered by one's intellectual faculties and is also affected by the different inter-connecting dimensions within oneself and the environment. However, Intelligence is not always about the brain's works. Still, it comprises the product of one's mind, body, heart, and soul's work.

The human body consists of different parts, purposes, and essential senses. One affects and even supports the other and vice versa. These parts and senses 
Abdulwahid | Social Factor Effects on Linguistic Performance, Emotional and Spiritual Intelligence

harmoniously work and connect to function well to arrive at an excellent work or output. This harmonious working together demonstrates how intelligence work (Jean et al., 2020). Since human beings have diverse mental abilities, they should have adequate focus, attention, and constant development. One should focus on testing, developing, and even enhancing the analytical ability and developing and improving other skills, such as emotional and spiritual abilities.

Today's curriculum should not only cater to some or even a few mental abilities, but it should also cater to the development and improvement of other students' abilities to attain quality students' performances. The multiple intelligence theory has a problem in its actualization in the different teaching-learning processes $(\mathrm{Yu}$, 2017). This theory suggested that all students' multiple intelligence should be developed equally. Rural schools, especially those remote ones with a lack of teachers, attest that the various intelligence of the students is hardly developed. It is a big challenge for every school and every teacher to cater to all students' needs and intelligence.

The word emotion comes from the French word esmovoir, which has the meaning to stir up. It is also coming from the Latin emovere, which has the purpose of moving or displacing. The emotions will lead people to push for an action effectively and to adapt to the situation. Emotions do not only interfere with the excellent decision that one made, but they are much essential and too critical for all individuals to decide effectively (Emmerling et al., 2008). According to Goleman (Cassidy et al., 2014), it is about "Managing feelings so that they are expressed appropriately and effectively, enabling people to work together smoothly toward their common goals". Emotional Intelligence is one's ability to identify, regulate, respond, enrich and improve emotion in oneself and others.

Spiritual intelligence is "The soul's intelligence. It is the intelligence with which heals people and with which people make themselves whole" (Zohar, 2012). Spiritual Intelligence is considered the ultimate human ability to absorb things naturally, systematically, and justly what is happening around and act with decency and justice on the truth and reality.

From an Islamic perspective, religion and spirituality are not distinct and separate because thoughts and actions should go hand in hand in executing any given task (Nasr, 2003). From the Islamic context, religion encompasses the whole life. Spirituality is a feeling and conviction that one has a connection to someone or something. This connection might benefit oneself while living in this world, whether because of their positive perception and conceptualization. Perception and conceptualization affect some people to treat others better and respect other people with kindness and compassion. They believe and consider themselves connected to others in some different context or form. There are various forces, being, and unexplained phenomena that encompasses human being. These being may or may not drive people to go astray in spirituality, such as contemplation, and most science cannot explain many of these phenomena. 
Abdulwahid | Social Factor Effects on Linguistic Performance, Emotional and Spiritual Intelligence

Spiritual intelligence triggers human beings to pursue the truth, believe the truth, and work hard for the fact. People who display a higher level of spiritual intelligence spend their whole life searching for the ultimate truth, especially the real meaning and purpose of life (Arnout, 2020). An Individual possesses spiritual intelligence, but sometimes people are polluting this intelligence, especially when they give more time and focus on the sweetness of worldly life, such as arrogance, power, greed, and many more. People are only staying in this world once. It is irrational if people are wasting most of their time and life doing unnecessary matters. People with higher spiritual intelligence use all their faculties, such as their material world, to realize the ultimate truth.

Real happiness can be achieved with the correct utilization of spiritual intelligence. Spiritual intelligence is the highest form of intelligence that human beings can possess. This intelligence makes individuals operate, manipulate, and combine other intelligence to attain the ultimate purpose in life. However, it does not work singly in many situations. Sometimes it needs several other intelligence to function maximally and productively (Masyhuri et al., 2020). The aid of other intelligence to spiritual intelligence, whether how small or how huge their contributions, depends from person to person. Spiritual intelligence aids individuals in a holistic and accurate view of life. It always accommodates past experiences, learnings, and realization. It reinterprets and evaluates them. Hence, people attained the ultimate realization of life, leading to being a better person in the future.

Vygotsky posited that the socio-cultural and the fundamental societal factors affect mental function because of the internalization and organization of the society (Daniels, 2005). School indeed comprises of students having different social statuses and cultural orientations. These various social statuses and cultural orientations play a significant role in molding students' mental capabilities. Families belonging to the upper class of the social status could afford good schooling for their children. They could also afford to buy additional learning materials, equipment, and gadgets that their children could use in their education, especially during the pandemic when online classes are the new trends in teaching-learning processes. In addition, families with a solid cultural orientation could motivate students to be active in their studies and succeed in their chosen careers. Individual needs strong support, not only from home but also from friends and relatives so their momentum in seeking knowledge would not be depleted. Many studies show that there are relationships and effects of societal factors on students' performance (Olsen, 1992). For the students to achieve success in the future, they should be surrounded by supportive parents. They should be in an environment where strong student support is fostered, and education is deemed the utmost priority.

There is an effect of societal factors on the mental functioning of the learner, and it also has a significant impact on emotional intelligence score (Margavio et al., 2012). Although lesser importance is given to emotional intelligence by the 
Abdulwahid | Social Factor Effects on Linguistic Performance, Emotional and Spiritual Intelligence

different schools worldwide, it is significantly related to linguistic performance (Abdulwahid, 2017). Students with a higher level of emotional intelligence most likely to have a higher level of linguistic performance. Countries that excel in their education, like Singapore and Australia, give more importance to developing and improving students' emotional intelligence. Investment in emotional intelligence could translate to students' cognitive intelligence investment since they are significantly related.

The emotional intelligence of the students results in the ability to perceive emotions in one own self and others and to understand clearly, regulate correctly, and make use of the information in different productive ways (Brannick et al., 2009). Students' emotional intelligence is coined with cognitive capabilities, and desirable responses are elicited now and then. Sometimes, IQ is not enough to respond to complex and critical problems and consistently succeed in arriving at the most desirable solution to a problem. Emotional intelligence plays a vital role, especially during times wherein social responsibility is needed the most. For example, one will help another person while one personal life is sometimes at risk.

IQ will stop one person from helping others, especially when his life is at stake, while emotional intelligence will drive one person to take chances to save the life of the one who needs the most help.

On a day-to-day basis, IQ and emotional intelligence sometimes fall short deficient in giving the right solution to complex human problems every day. Spiritual intelligence is necessary for an individual to respond holistically and correctly, especially to a complicated and crucial issue. Robert Emmons stated that spiritual intelligence is "the adaptive use of spiritual information to facilitate everyday problem solving and goal attainment" (Srivastava, 2016). Sometimes, humans use spiritual intelligence in solving problems in life but are not aware of utilizing or benefitting from it already. Some issues are not entirely and rightly solved by IQ nor emotional intelligence. Sometimes IQ, emotional intelligence, and spiritual intelligence should work together to respond correctly and efficiently to various complex and crucial problems that the human race is facing. People with higher spiritual intelligence will understand the purpose of life, the connection among the human race, human connection to other creations, existence, and spiritual beings and phenomena wherein science cannot explain.

Spiritual intelligence is vital and displays a significant role in an individual's life, especially in the pursuit of happiness and contentment, just like IQ and emotional intelligence. Spiritual intelligence is somehow affected by societal factors (Pant \& Srivastava, 2014; Abdulwahid, 2017). Desirable societal factors should support one to achieve superior spiritual intelligence.

\section{Human Growth and Development}

In human development, the adolescence stage is the most complicated in developing human growth and personality. The adolescence stage most probably 
Abdulwahid | Social Factor Effects on Linguistic Performance, Emotional and Spiritual Intelligence

falls under the high school level. Sometimes, high school students are not content with who they are and dream of becoming someone because they want to impress other people, such as classmates, friends, teachers, and even their parents. They want to impress other people so that they will be very proud of them. Sometimes, they will conflict with their inner selves as they brand their parents, classmates, and even themselves. Most of the time, students prefer to listen to their friends instead of their parents, especially when they affiliate with gang groups. Here, the spiritual intelligence of the students is not yet fully developed. Students are not contented with their life and not at peace with themselves. That is why they want to become somebody for their pride and discontentment. People with the highest level of spiritual intelligence tend to find peace in themselves, do not ask for more, and are not negatively affected by their things.

In Freud's so-called genital stage of adolescence (Waldo, 2014), high school students should strive to self-control from their consistent disruptive behavior, unpredictable moods, and toxic feeling and vibes. They should not only try to understand their feelings and emotions, but most significantly, they have to respect, care for, and understand other people's feelings, emotions, and behavior. The emotional intelligence of the high school students should be developed at this stage so much so they could control their emotions and feelings because the inability to regulate emotion could result in negative behavior such as mood swings, frustration, uncontrolled anger, etc.

Other students also experience mixed emotions and exhibit unpredicted mood swings, which are often difficult to understand. So, at this stage, students should control and strive to be the best they can as far as their feelings, behaviors, and emotions are concerned. Students should mingle with other people they identified with and maintain healthy behavior, emotions, and feelings as they progress to their next stage in life.

During the adolescence stage, most high school students find difficulty arriving at sound decisions for themselves and other people. They start to question authority figures who are in power and the complexities of their society. It could frustrate them and can stir up rebellious anger and action. That is why one can observe many youth demonstrations every time in different places, particularly against the government. At this juncture, youth emotional and spiritual intelligence should be uplifted. Instead of seeing the negative aspect of other people or the government, they should appreciate the great things other people and the government have done for them. Violence can never solve anything, yet it might trigger society or national instability. One should ask what he or she has contributed to the people and the government and not always the other way around.

High school students are also rebellious to their parents because they want to conform to their group, especially their gang group. Sometimes, they are unmindful of the advice of their parents and, at times, their teachers. Piaget 
Abdulwahid | Social Factor Effects on Linguistic Performance, Emotional and Spiritual Intelligence

referred to this state as the formal operational stage (Shaffer \& Kipp, 2013). Here, high school students are in the process of developing and forming their identities. In short, they want to be like other people and not being content with themselves. Parents, in particular, have given their lives to their children. They go through difficulties and sacrifices in life, yet children do not realize them because their emotional and spiritual intelligence is not fully developed. Schools could design programs that help develop students' emotional and spiritual intelligence to value the sacrifices and difficulties parents faced while rearing their children.

There are a lot of positive qualities high school students usually portray. They can use inductive and deductive thinking inside or outside the classroom; determine and follow the root causes of one problem; also construct bits of ideas and come up with the general idea. They can reason out as to the consequences of their actions. Teachers and parents should always be available for their children or learners and should always be hands-on in guiding them. They can continually develop and initiate positive thinking and let their children or students become responsible adolescents at home, school, and their community.

Erikson has associated adolescence as the "Identity Versus Role Confusion" (Pressley \& McCormick, 2006). During this stage, adolescents start to determine and question their role in society, at home, school, and other places. Mostly, they always try to alter their behavior to discover their true identity. One day, they want to become a hero at school and in the community. On some other days, they want to be simply alone. They do not want anybody to notice them. Failure to achieve an identity during adolescence might result in self-confusion, especially in their later stage of development. For instance, they do not know and are often confused as to their role in society. Strong support and consistent guidance from parents, teachers, and others are essential to establish their identity and know what they want for their lives in the future. The development of a higher level of spiritual intelligence is necessary. Spiritual intelligence will make students understand themselves better. They would realize their connection and their oneness to other beings. Humans are not independent beings, but they are connected and have a solid relationship to everything surrounding them, whether human beings, animals, and other inanimate objects. They are being affected by things that surround them, and they are also affecting everything around them; sometimes, they realize them and sometimes do not.

The earliest theorists like Pavlov and Watson argued that classical conditioning is critical in teaching and learning (Daniels, 2005). Human tends to do good or bad depending on the environment and the family. Children with supportive parents will be likely to succeed. In contrast, parents with less social support would most probably struggle in their schooling and have a strong tendency to experience failures or, worst, drop from studies.

Pavlov and Watson claimed that every human could be transformed into a better one if given a good environment and experience. On the other hand, a human can be transformed into a criminal or a bad one if given evil and hostile 
Abdulwahid | Social Factor Effects on Linguistic Performance, Emotional and Spiritual Intelligence

environments. They do not subscribe to the idea that some humans possess a natural evil or wicked mind.

In addition, Skinner explained that positive and negative reinforcement increases behavior, response, or performance, while positive and negative punishment reduces the behavior, reaction, or performance of a specific individual or the learner in particular. For instance, to initiate active participation among students, it should be accompanied by a reward system, such as by saying "very good" if the student gets the correct answer. However, if they fail to answer, then they will receive failing marks. Although this idea is practiced by many teachers in education, some cases wherein students who will be given continuous negative responses will become rebellious to their teachers. Sometimes, they will lose interest and be no longer attentive and participative inside the classroom. Thus, teachers should be vigilant enough to encounter students who show hostile or suspicious behavior inside the school because this problem may increase and may become a more complicated one.

Human learning and development are affected by their surroundings, environment, and society. The social and the culture interact with the students' acquisition of language, behavior, personality, and the like, as was confirmed by Vygotsky. For Vygotsky, organized social and cultural environments inherent human behavior. The students learn their behavior, way of thinking, mannerism, and other matters from their parents. They also have accommodated consciously and unconsciously other peoples' behavior, the way of thinking, characteristic from their classmates, friends, and even strangers (Fidalgo \& Magalhães, 2020). Sometimes, they are adapting and executing other people's ideas, behavior, and the like automatically. Sometimes they suppress these ideas, behavior, and the like if their minds contradict them. For example, human language acquisition, behavior, and personality are due to social and cultural intervention. However, humans can filter this intervention to decide what to accommodate, believe, subscribe, and take in, besides their total behavior and total being in general. As such, it can be manifested in their way of life. This study aims to determine if the social factors affect the students' linguistic performance, emotional and spiritual intelligence.

\section{METHODS}

The study examined the effect of some social factors on the linguistic performance, emotional and spiritual intelligence of grade nine Muslim high school students in Bongao, Tawi-Tawi, Philippines, and Yogyakarta, Indonesia, who were enrolled in private schools. The independent variables of this study are the social factors which included: 1. Students' family/guardian (monthly income, educational attainment, occupation, and religiosity) and 2. Students' experiences (involvement in the social group, access to social media, and madrasah experienced). The dependent variables are three-folds: linguistic performance, emotional, and spiritual intelligence of the grade nine students. The 
Abdulwahid | Social Factor Effects on Linguistic Performance, Emotional and Spiritual Intelligence

questionnaires used in this study were: 1. USM Emotional Quotient Inventory (an assessment of self-report measure of emotional intelligence developed by Yusoff, Rahim, \& Esa), 2. Spiritual Intelligence Self-Report Inventory (an evaluation of a self-report measure of spiritual intelligence developed by King \& DeCicco), and 3. Linguistic Performance Test (a test on grade nine Muslim high school student's performance on four linguistic skills: listening, speaking, reading, and writing).

\section{RESULTS AND DISCUSSION}

\section{Linguistic Performance}

\section{a. Family Religiosity}

Table 1. Significant Differences in the comparisons of the Mean Scores between Family Religiosity in Linguistic Performance

\begin{tabular}{|c|c|c|c|c|}
\hline \multicolumn{2}{|c|}{ Religiosity } & \multirow{2}{*}{$\begin{array}{c}\text { Mean } \\
\text { Difference } \\
-3.168\end{array}$} & \multirow{2}{*}{$\begin{array}{c}\text { Level of } \\
\text { Significance } \\
\text { @ } 0.05 \\
0.862\end{array}$} & Interpretation \\
\hline \multirow{3}{*}{$\begin{array}{l}\text { Very } \\
\text { Religious }\end{array}$} & Religious & & & Not Significant \\
\hline & Somewhat Religious & -4.637 & 0.664 & Not Significant \\
\hline & Not Religious & -13.100 & 0.055 & Not Significant \\
\hline \multirow[t]{2}{*}{ Religious } & Somewhat Religious & -1.469 & 0.932 & Not Significant \\
\hline & Not Religious & -9.932 & 0.016 & Significant \\
\hline $\begin{array}{l}\text { Somewhat } \\
\text { Religious }\end{array}$ & Not Religious & -8.463 & 0.120 & Not Significant \\
\hline
\end{tabular}

Source: Author

The analysis of variance (ANOVA) was utilized and pointed out a significant difference of 0.041 at the 0.05 alpha level. The Gabriel Post-hoc test determined that the critical difference is between students with no religious and religious parents at a significant value of 0.016 at the 0.05 alpha level. The result shows that students with no religious parents are significantly different from students with spiritual parents, particularly their listening skills. It is suspected that religious parents tend to guide and teach their children on matters related to their religion. In contrast, they tend to give less importance to school matters, particularly their children's linguistic performance. It may be why students' listening skill in the English language is poorly developed for those students whose parents are religious.

Religious practice (e.g., frequent prayer, family religious instruction, and the like) displays a significant positive impact on college students' academic attainments. It is expressed that the more faithful a person's spiritual practices resulted in better grades at both high school and college levels (LaRose, 2009). One study reported that students whose families attended religious gatherings acquired higher academic performance than those whose parents did not have "religious involvement" (Dijkstra \& Peschar, 1996). Their finding is different from this 
Abdulwahid | Social Factor Effects on Linguistic Performance, Emotional and Spiritual Intelligence

study might be because of the variable being considered. Their variable is academic achievement, while it is linguistic performance in this case. In this study, the students whose parents are not religious performed better than those students whose parents are religious as far as linguistic performance is concerned.

It is not wrong to become religious. However, parents should not forget that they also must educate their children properly. They should confidently delegate schooling responsibilities to the teachers and learning institutions for their children's learning and education (Yusri et al., 2020). Parents should constantly develop and understand children's academics, mainly linguistic performance, and developing their emotional and spiritual intelligence. Religious parents should also provide their children with an environment that could lead to learning and improve students, linguistic skills, and other essential skills. Parents should not only send their children to good schools, but they should also provide their children with good experience and environment, especially those that could lead to students' development and improvement of their linguistic performance.

In a nutshell, religious parents should focus on helping develop their children's linguistic performance. Based on the result of this study, their children lag or differed negatively from those students whose parents are not religious.

\section{b. The Social Group}

Table 2. Significant Differences in the comparisons of the Mean Scores between Students' Involvements in the Social Group on Linguistic Performance

\begin{tabular}{|l|l|c|l|l|}
\hline \multicolumn{2}{|l}{ Involvement in the Social Group } & $\begin{array}{c}\text { Mean } \\
\text { Difference }\end{array}$ & $\begin{array}{c}\text { Level of } \\
\text { Significance } \\
@\end{array}$ & 0.05 \\
Heavily Involved & Involved & 10.083 & 0.183 & Not Significant \\
\hline & Somewhat Involved & 12.538 & $\mathbf{0 . 0 3 1}$ & Significant \\
\hline & Not Involved & 14.043 & $\mathbf{0 . 0 1 9}$ & Significant \\
\hline Involved & Somewhat Involved & 2.455 & 0.636 & Not Significant \\
\hline & Not Involved & 3.960 & 0.247 & Not Significant \\
\hline $\begin{array}{l}\text { Somewhat } \\
\text { Involved }\end{array}$ & Not Involved & 1.505 & 0.938 & Not Significant \\
\hline
\end{tabular}

Source: Author

This study revealed a significant difference in terms of the students' linguistic performance as far as involvement in the social group is concerned. The ANOVA revealed a practical value of 0.026 , which is lower than the alpha level of 0.05 . The Gabriel Post-hoc test determined that the significant differences are between heavily involved and somewhat involved and heavily involved and not involved students in the social group with substantial values of 0.031 and 0.019 . The best combination of variables, as shown in the table, did not yield any significant difference. 
Abdulwahid | Social Factor Effects on Linguistic Performance, Emotional and Spiritual Intelligence

The findings are similar to other studies conducted (Mingle \& Adams, 2015) that claims social group does improve students' reading skills. This study also shows similar results as other studies (Yunus \& Salehi, 2012). Students achieved more vocabulary and even improved their writing skills due to the social group experience, such as Facebook and Twitter. Social Network Sites (SNS) provide an opportunity for the adolescent to engage in communities that can facilitate learning and practice their skills in a specific knowledge area (Ahn, 2011; Yunus \& Salehi, 2012). Students who participated in social media showed improved reading skills due to gaining more vocabulary and improving writing skills.

However, some studies (Banquil, et al., 2009; Kirschenr \& Karpinski, 2010) reported an adverse effect and claimed that engagement in the social group could result to students poor grades and including academic performance due to lack of study time. Students should make use of the internet, especially social media, wisely. Students joining the social group should have a good intention and be sure that it will benefit them. Otherwise, it could have a significantly negative effect on them. For example, they would become addicted to some non-beneficial sites or programs on the internet wherein their time for study is being disturbed, and worse, they will not study their lesson.

Involvement in social media positively affected the students' linguistic performance based on the result of this study, especially those heavily involved or used social media. Students should look for social groups that could improve their linguistic skills and avoid social groups, negatively affecting students' learning (Bahiroh \& Suud, 2020). Social effect in terms of involvement in the social group significantly affects the students' linguistic performance positively.

\section{c. Madrasah Experience}

Table 3. Significant Difference in the comparison of the Mean Scores between Madrasah Experiences in the Linguistic Performance

\begin{tabular}{|lcccl|}
\hline Madrasah Experience & $\begin{array}{c}\text { Mean } \\
\text { Difference }\end{array}$ & $\begin{array}{c}\text { Level of } \\
\text { Significance @ 0.05 }\end{array}$ & Interpretation \\
\hline With & Without & 3.704 & 0.034 & Significant \\
\hline
\end{tabular}

Source: Author

In madrasah experience, grade nine Muslim students with madrasah experience performed significantly better than those without experience, with a mean difference of 3.704 in linguistic performance. The Independent sample t-test shows a significant difference in equal variances assumed with a considerable value of 0.034 at 0.05 alpha level. This study confirms that the language experience, such as additional language learning in madrasah, significantly affects linguistic performance. This study is consistent with most findings that foreign language experience is related to English linguistic skills. Studying a foreign language helps students acquire English language skills (Rafferty, 1986). It also improved students' grammatical judgment, correction tasks, and word recognition (Demont, 2001). In other studies, it could also improve students' 
Abdulwahid | Social Factor Effects on Linguistic Performance, Emotional and Spiritual Intelligence

word-knowledge, reading, language, and spelling (Sheridan, 1976). Foreign language experience will let students acquire higher scores in the English achievement test (Olsen \& Brown, 1992). The length of foreign language study is positively related to student success in the standardized test (Cooper, 1987). Students are also expected to perform better in college (Wiley, 1985) and performed significantly better in reading ability than those who do not have foreign language experience (Diaz, 1982). Bilingual skilled readers were reported to score higher on word-reading and spelling tasks than monolingual proficient readers (D'Angiulli et al., 2001).

In terms of the Arabic language, this study supports finding a significant relationship between Arabic language proficiency and English language proficiency (Zamlut, 2011), particularly reading fluency. This study also confirmed that students who were proficient in Arabic writing skills performed significantly better in English writing skills (Dweik \& Abu Al Hommos, 2007).

The finding mentioned above implies that students should add more experiences to foreign language learning, especially Arabic language learning, because it significantly improved students' linguistic performance. Foreign language learning could support students to attain a high level of linguistic skills. This study shows that spending extra time to study a foreign language positively affected students' linguistic performance. Studying Arabic subjects and Islamic studies could have worldly gains and have a significant increase in the hereafter. It is posited here that social factor such as the Madrasah experience showed a significant positive effect on students' linguistic performance.

\section{Emotional Intelligence}

\section{a. Family Income}

Table 4. Significant Differences in the Comparison of the Mean Scores between Students' Family Incomes on the Emotional Intelligence

\begin{tabular}{|c|c|c|c|c|}
\hline \multicolumn{2}{|c|}{ Family Income } & \multirow{2}{*}{$\begin{array}{c}\text { Mean } \\
\text { Difference } \\
-8.941\end{array}$} & \multirow{2}{*}{$\begin{array}{c}\begin{array}{c}\text { Level of } \\
\text { Significance } \\
\text { @ } 0.05 \\
0.887\end{array}\end{array}$} & \multirow{2}{*}{$\begin{array}{l}\text { Interpretation } \\
\text { Not Significant }\end{array}$} \\
\hline High/Extremely & Moderate & & & \\
\hline & Low & -29.800 & 0.035 & Significant \\
\hline & Very Low & -29.550 & 0.127 & Not Significant \\
\hline \multirow[t]{2}{*}{ Moderate Income } & Low & -20.859 & 0.013 & Significant \\
\hline & Very Low & -20.609 & 0.198 & Not Significant \\
\hline Low Income & Very Low & .250 & 1.000 & Not Significant \\
\hline
\end{tabular}

Source: Author

Table 4 presents the significant differences in comparing the mean scores between students with high or extremely high, moderate, low, and very lowincome parents. The ANOVA reveals a considerable difference in the students' emotional intelligence regarding students' family or guardian income by 0.002 
Abdulwahid | Social Factor Effects on Linguistic Performance, Emotional and Spiritual Intelligence

significance at the 0.05 alpha level. The Hochberg post-hoc test, as shown in the table, reveals that significant differences are among students who have lowincome and high or extremely high-income parents and low-income and moderate high-income parents with 0.035 and 0.013 important values, respectively at 0.05 alpha level. Students with low-income parents are significantly different from high or extremely high and moderate-income parents regarding emotional intelligence.

This study is consistent with findings that parents' income has a significant positive relationship with emotional intelligence (Rauf, et al., 2013). This study has similar findings (Sharma \& Vaid, 2005) that low-income families' children have significantly better emotional intelligence than adolescents belonging to middle-income families. However, this study contradicts the findings where students with wealthy families were substantially better than students with lower-income families and not the other way around (Harrod \& Scheer, 2005). However, the research found that rich people tended to show lesser empathy, less caring, and not as compassionate as poor people (The New York Times). This study is in congruence with most studies claiming that low-income families had a high level of emotional intelligence than the rich ones.

Parents with low-income earnings significantly affect students' emotional intelligence when there are continuous guidance and supervision to mold students to be the best they can. If not constantly, these parents are always at home, and now and then are developing their children's emotional intelligence and other intelligence, whether knowingly or unknowingly. Spending time with children at home does not only mean giving them moral and social support for them to be successful in life, but it can also mean the development and improvement of children's intelligence.

Even though high-income parents could provide their children with the necessary environment to mold their personality or emotional intelligence, they still cannot guide and support when they are not at home. Hence, the children cannot achieve emotional intelligence. Enough income and solid support and guidance by the parents are vital for students to attain a higher level of emotional intelligence.

\section{b. Parents Education}

Table 5. Significant Differences in the comparisons of the Mean Scores between Students' Family/Guardian Education on the Emotional Intelligence

\begin{tabular}{|c|c|c|c|c|}
\hline \multicolumn{2}{|c|}{$\begin{array}{l}\text { Students' Parent/ } \\
\text { Guardian Education }\end{array}$} & $\begin{array}{c}\text { Mean } \\
\text { Difference }\end{array}$ & $\begin{array}{c}\text { Level Of } \\
\text { Significance }\end{array}$ & Interpretation \\
\hline \multirow{3}{*}{ Post Graduate } & Undergrad. & 5.556 & 0.967 & Not Significant \\
\hline & High Sch. Grad. & 1.481 & 1.000 & Not Significant \\
\hline & $\begin{array}{l}\text { Elementary } \\
\text { Graduate }\end{array}$ & -7.540 & 0.991 & Not Significant \\
\hline
\end{tabular}


Abdulwahid | Social Factor Effects on Linguistic Performance, Emotional and Spiritual Intelligence

\begin{tabular}{|c|c|c|c|c|}
\hline \multicolumn{2}{|c|}{$\begin{array}{l}\text { Students' Parent/ } \\
\text { Guardian Education }\end{array}$} & $\begin{array}{c}\text { Mean } \\
\text { Difference }\end{array}$ & $\begin{array}{c}\text { Level Of } \\
\text { Significance } \\
\text { @ } 0.05\end{array}$ & Interpretation \\
\hline \multirow{4}{*}{ Undergraduate } & Others & -25.111 & 0.191 & Not Significant \\
\hline & High Sch. Grad. & -4.074 & 0.990 & Not Significant \\
\hline & $\begin{array}{l}\text { Elementary } \\
\text { Graduate }\end{array}$ & -13.095 & 0.627 & Not Significant \\
\hline & Others & -30.667 & 0.029 & Significant \\
\hline \multirow[t]{2}{*}{$\begin{array}{l}\text { High School } \\
\text { Graduate }\end{array}$} & $\begin{array}{l}\text { Elementary } \\
\text { Graduate }\end{array}$ & -9.021 & 0.957 & Not Significant \\
\hline & Others & -26.593 & 0.113 & Not Significant \\
\hline $\begin{array}{l}\text { Elementary } \\
\text { Graduate }\end{array}$ & Others & -17.571 & 0.799 & Not Significant \\
\hline
\end{tabular}

Source: Author

The ANOVA pointed out a significant difference in the levels of emotional intelligence in terms of parents' or guardians' educational attainment, which reflected in a substantial value of 0.027 at 0.05 alpha level. The Hochberg Posthoc test revealed that the critical difference is between undergraduate parents and those whose parents did not graduate even the elementary level at a significant value of 0.029 at 0.05 alpha level.

This study is consistent with other studies (Harrod \& Scheer, 2005; Rauf et al., 2013) that stressed a significant difference in emotional intelligence regarding family education of high school students. On the contrary, another study (Chen et al., 2006) did not significantly differentiate parents' education level on students' emotional intelligence. It is attributed that the insignificant result was due to limitations of the study. The conflicting result (Saygili, 2015) was due to the age differences of the respondents and the instrument.

Students whose parents have an undergraduate degree do significantly differ from those whose parents do not even graduate from an elementary level. Parents who have a degree have many experiences and learned a lot, especially during their undergraduate schooling. These parents' experiences, inside or outside the school, somehow have affected their children's different bits of intelligence, especially on emotional intelligence. In parents' education, social factors affected the emotional intelligence of the high school student.

\section{c. Madrasah Experience}

Table 6. Significant Difference in the comparison of the Mean Scores between Madrasah Experiences in the Emotional Intelligence

\begin{tabular}{|l|l|cc|l|}
\hline \multicolumn{2}{|c}{ Madrasah Experience } & $\begin{array}{c}\text { Mean } \\
\text { Difference }\end{array}$ & $\begin{array}{c}\text { Level Of } \\
\text { Significance @ 0.05 }\end{array}$ & \multicolumn{1}{|c|}{ Interpretation } \\
\hline $\begin{array}{l}\text { With } \\
\text { Experience }\end{array}$ & $\begin{array}{l}\text { Without } \\
\text { Experience }\end{array}$ & 11.321 & 0.014 & Significant \\
\hline
\end{tabular}


Abdulwahid | Social Factor Effects on Linguistic Performance, Emotional and Spiritual Intelligence

\section{Source: Author}

The grade nine Muslim students with madrasah experience performed significantly better, with a mean difference of 11.321 on emotional intelligence. The Independent sample t-test shows a significant difference in equal variances assumed with a substantial value of 0.014 at 0.05 alpha level. Madrasah usually teaches students to be at peace, not only with human beings but also with other creations such as plants, animals, and other beings. Development of good behaviors and other desirable qualities and characteristics and the like are always taught in madrasah, and this could add to the improvement of students' emotional intelligence.

There is a significant difference between Islamic schools and madrasah students on emotional intelligence (Nikhat, 2016). Islamic school students have significantly higher emotional intelligence than madrasah students, while one study determined the significant relationship between emotional intelligence and self-adjustment among madrasah students at Madrasah Aliyah (Kurniawan, 2013).

It is theorized here that social factors, such as madrasah experience, affect the students' emotional intelligence. Madrasah's experience should not be a hindrance to students' education. Still, it should be promoted because it significantly affects academic or linguistic performance and students' emotional intelligence (Khaidir \& Suud, 2020). Islam teaches Muslims to give importance to world affairs and, most notably, to spiritual matters. For example, Muslim parents should send their children to a secular school and religious school. They could also provide students with experience or environment for religious learning, such as enrolling their children in a summer class, tutorials, and the like.

\section{Spiritual Intelligence}

Table 7. Significant Differences in the comparisons of the Mean Scores between Students' Involvements in the Social Group on Spiritual Intelligence

\begin{tabular}{|c|c|c|c|c|}
\hline Involvemer & In The Social Group & \multirow{2}{*}{$\begin{array}{c}\text { Mean } \\
\text { Difference } \\
\\
22.426\end{array}$} & \multirow{2}{*}{$\begin{array}{c}\text { Level Of } \\
\text { Significance } \\
\text { @ } 0.05 \\
0.075\end{array}$} & \multirow{2}{*}{$\begin{array}{l}\text { Interpretation } \\
\text { Not Significant }\end{array}$} \\
\hline Heavily & Involved & & & \\
\hline Involved & Somewhat Involved & 21.462 & 0.089 & Not Significant \\
\hline & Not Involved & 25.638 & 0.027 & Significant \\
\hline \multirow[t]{2}{*}{ Involved } & Somewhat Involved & -.964 & 1.000 & Not Significant \\
\hline & Not Involved & 3.212 & 0.901 & Not Significant \\
\hline $\begin{array}{l}\text { Somewhat } \\
\text { Involved }\end{array}$ & Not Involved & 4.176 & 0.588 & Not Significant \\
\hline
\end{tabular}

Source: Author

The ANOVA points out a significant difference in spiritual intelligence regarding students' involvement in the social group with a substantial value of 0.031 , which 
Abdulwahid | Social Factor Effects on Linguistic Performance, Emotional and Spiritual Intelligence

is lower than the alpha level of 0.05 . The Hochberg Post-hoc test, as shown above, reveals that the significant differences are between heavily involved and not involved at a substantial value of 0.027 at 0.05 significant alpha level.

Social factors, such as social media, significantly affected students' spiritual intelligence positively. Students heavily involved in the social group are substantially different from students who are not engaged in social media regarding their spiritual intelligence. Students who are heavily involved in social media can perceive the transcendence dimension of themselves within or toward other people or in any given situation (Andriyani et al., 2020). They join the social group because they believe that they are connected to other people in different ways. They do not only see material or physical matters or beings, but they can visualize their connectedness with other people, especially to or in their social group. They do not treat their fellow members in the social group as just friends, but their treatment goes beyond, and they seem to feel like brothers and sisters and are connected in some other ways.

The social group gives the students opportunities to connect with other people mutually, but it can improve their spiritual connectedness to other people or friends. This group can help improve the students' perception from a materialistic one to that of the spiritual one. For example, helping others is not only for worldly rewards, but sometimes it goes beyond the worldly benefits and gains depending on one's faith and belief.

\section{CONCLUSIONS}

This study sought to determine the significant difference among students' social factors such as 1) students' family (monthly income, educational attainment, occupation, and religiosity); and 2) Students' experience (involvement in the social group, access to social media, and madrasah experience) in linguistic performance, emotional, and spiritual intelligence. Specifically, it sought to answer this question: Is there a significant difference between grade nine Muslim students' social factors on linguistic performance, emotional and spiritual intelligence?

This study showed a significant difference between the social factors of grade nine Muslim students on linguistic performance, emotional and spiritual intelligence. Social factors that are significantly different in linguistic performance are family religiosity, social group, and the madrasah experience. Social factors that yield a significant difference in the students' emotional intelligence are family income, parents' education, and madrasah experience. In contrast, the social factor that showed a considerable difference in spiritual intelligence is students' involvement in the social group.

Regarding linguistic performance, students whose parents were not religious were significantly better than students with spiritual parents. Students heavily involved in the social group were considerably better than those who were 
Abdulwahid | Social Factor Effects on Linguistic Performance, Emotional and Spiritual Intelligence

somewhat and not engaged in the social group. Students who had madrasah experience were significantly different from those who did not as far as linguistic performance.

Students with low-income parents were significantly different from high or extremely high and moderate-income parents regarding emotional intelligence. Students whose parents did not even graduate in elementary level are quite other from students who had undergraduate parents regarding emotional intelligence. Students who had madrasah experience were significantly different from those who had no madrasah experience regarding emotional intelligence. As far as spiritual intelligence is concerned, students who were heavily involved in the social group were significantly better than those who were somewhat involved in the social group.

\section{REFERENCES}

Abdulwahid, K. S. (2017). Linguistic performance, emotional and spiritual intelligence of grade nine muslim students in Yogyakarta, Indonesia and Bongao, Tawi-Tawi, Philippines. International Journal of Education Development, Society and Technology, 5(8), 65-74.

Ahn, J. (2011). The effect of social network sites on adolescents' social and academic development: Current theories and controversies. Journal of the American Society for Information Science and Technology, 62(8), 1435-1445. https:// doi.org/10.1002/asi.21540

Andriyani, I. N., Wasim, A. T., Zainuddin, M., \& Suud, F. M. (2020). Gadgets playing behavior of students in Indonesia. Humanities $\mathcal{E}$ Social Sciences Reviews, 8(1), 264-271. https://doi.org/10.18510/hssr.2020.8137.

Arnout, B. A. (2020). A structural equation model relating unemployment stress, spiritual intelligence, and mental health components: Mediators of coping mechanism. Journal of Public Affairs, 20(2), 2020;20:e2025. https:// doi.org/10.1002/pa.2025

Bahiroh, S., \& Suud, F. M. (2020). Preventive counseling: A religious development program at boarding school in Yogyakarta. Humanities $\mathcal{E}$ Social Sciences Reviews, 8(2), 614-23.

Banquil, K., Chuna, N. A., Leano, G. A., Rivero, M. A., Bruce, C. A., Dianalan, S. N., Matienzo, A. R., \& Timog, N. U. (2009). Social networking sites affect one's academic performance adversely. UST College of Nursing, 1-42.

Brannick, M. T., Wahi, M. M., Arce, M., Johnson, H. A., Nazian, S., \& Goldin, S. B. (2009). Comparison of trait and ability measures of emotional intelligence in medical students. Medical education, 43(11), 1062-1068. 
Abdulwahid | Social Factor Effects on Linguistic Performance, Emotional and Spiritual Intelligence

Cassidy, C., Kreitner, B., \& VanHuss, S. (2014). Administrative management: Setting people up for success. Cengage Learning, 54.

Chen, F. S., Lin, Y. M., \& Tu, C. A. (2006). A study of the emotional intelligence and life adjustment of senior high school students. World transactions on engineering and technology education, 5(3), 473.

Cooper, T. C. (1987). Foreign language study and SAT-verbal scores. The Modern Language Journal, 71(4), 381-387. https://doi.org/10.2307/328467

D'Angiulli, A., Siegel, L., \& Serra, E. (2001). The development of reading in English and Italian in bilingual children. Applied Psycholinguistics, 22(4), 479-507. https://doi.org/10.1017/S0142716401004015

Daniels, H. (2005). An introduction to vygotsky. Psychology Press, 35-38.

Demont, E. (2001). Contribution of early 2nd-language learning to the development of linguistic awareness and learning to read/Contribution de l'apprentissage précoce d'une deuxième langue au développment de la conscience lingustique et à l'apprentissage de la lecture. International Journal of Psychology, 36(4), 274-285. https:// doi.org/10.1080/00207590042000137.

Diaz, J. O. P. (1982). The effects of a dual language reading program on the reading ability of Puerto Rican students. Reading Psychology, 3(3), 233-238. https:// doi.org/10.1080/0270271820030305

Dijkstra, A., \& Peschar, J. L. (1996). Religious determinants of academic attainment in the Netherlands. Comparative Education Review, 40(1), 47-65. https://doi.org/10.1086/447355

Dweik, B. S., \& Abu Al Hommos, M. D. (2007). The Effect of Arabic Proficiency on the English Writing of Bilingual-Jordanian Students. Online Submission.

Emmerling, R. J., Shanwal, V. K., \& Mandal, M. K. (2008). Emotional intelligence: theoretical and cultural perspectives. Nova Publishers, 5. http://www.eiconsortium.org/Emotional_Intelligence_Theoretical_and_ Cultural_Perspectives.htm.

Encyclopedia Britannica. Retrieved from http://www.britan-nica.com /topic/human-intelligencepsychology on [08/23/15].

Fadhil, M. Y., \& Sebgag, S. (2021). Sufi approaches to education: The epistemology of Imam al-Ghazali. Nazhruna: Jurnal Pendidikan Islam, 4(1), 91-107. https://doi.org/10.31538/nzh.v4i1.834.

Fidalgo, S. S., \& Magalhães, M. C. C. (2020). The method in Vygotsky: social compensation to achieve higher psychological functions and social changes. Revisiting Vygotsky for social change: bringing together theory and practice. New York: Peter Lang. in print to be launched in, 193-212. 
Abdulwahid | Social Factor Effects on Linguistic Performance, Emotional and Spiritual Intelligence

Harrod, N. R., \& Scheer, S. D. (2005). An exploration of adolescent emotional intelligence in relation to demographic characteristics. Adolescence, 40(159), 503.

Jean, Shio-Shin, Ping-Ing Lee, and Po-Ren Hsueh. 2020. 'Treatment Options for COVID-19: The Reality and Challenges'. Journal of Microbiology, Immunology, and Infection 53 (3): 436-43. https://doi.org/10.1016/j.jmii.2020.03.034

Khaidir, E., \& Suud, F. M. (2020). Islamic education in forming students' characters at as-shofa Islamic High School, Pekanbaru, Riau. International Journal of Islamic Educational Psychology, 1(1), 50-63.

Kurniawan, Rezky. (2013). Hubungan antara kecerdasan emosional dengan penyesuaian diri pada siswa kelas X di Madrasah Aliyah Negeri 2 Batu. Diss. Universitas Islam Negeri Maulana Malik Ibrahim Malang. https://doi.org/10/07410026_Lampiran.pdf.

LaRose, R., A. (2009). The relationship between religiosity and educational pursuit and perception among college students at Utah State University. (Publication no. 444) [Dissertations, Utah State University]. https:// digitalcommons.usu.edu/etd/444

Margavio, T., Margavio, G., Hignite, M., \& Moses, D. (2012). A comparative analysis of the emotional intelligence levels of American and Chinese business students. College Student Journal, 46(4), 776-787. https://doi.org/10.1177\%2F1847979019880665

Masyhuri, S., Azhar, M., \& Suud, F. M. (2020). The Concept of Happiness for Islamic Community Of Melayu Kampar Riau Indonesia. Journal of Critical Reviews, 7(12), 833-838. http://dx.doi.org/10.31838/jcr.07.12.147

Mingle, J., \& Adams, M. (2015). Social media network participation and academic performance in senior high schools in Ghana. Library Philosophy and Practice, 1. http://digitalcommons.unl.edu/libphilprac/1286

Nasr, Seyyed Hossein. (2005). Islam: Religion, history, and civilization. Harper Collins E-Books, London.

Nikhat, F. K. (2016). A Study of Socio-Economic Status and Emotional Intelligence among Madrasa and Islamic School students towards Inclusive Development. European Academic Research, 11838-11851.

Olsen, S.A., \& Brown, L.K. (1992). The relation between high school study of foreign languages and act english and mathematics performance. ADFL Bulletin, 47-50. https:/ / doi.org/10.1632/adfl.23.3.47

Pant, N., \& Srivastava, S. K. (2014). Effect of spiritual intelligence on mental health and quality of life among college students. ZENITH: International Journal of Multidisciplinary Research,4(8), 208-215. https: / / doi.org/10.1007/s10943-017-0529-3 
Abdulwahid | Social Factor Effects on Linguistic Performance, Emotional and Spiritual Intelligence

Pant, N., \& Srivastava, S. K. (2019). The impact of spiritual intelligence, gender, and educational background on mental health among college students. Journal of religion and health, 58(1), 87-108.

Pressley, M., \& McCormick, C. B. (2006). Child and Adolescent Development for Educators. Guilford Press, 145-146.

Rafferty, E. A. (1986). Second language study and basic skills in Louisiana. U.S., Louisiana, from ERIC database. https:// eric.ed.gov/?id=ED283360r

Rauf, F. H. A., Tarmidi, M., Omar, M., Yaaziz, N. N. R., \& Zubir, N. I. D. M. (2013). Personal, family and academic factors towards emotional intelligence: A case study. International Journal of Applied Psychology, 3(1), 1-6.

Saygili, G. (2015). The factors affecting emotional intelligence of gifted children. Research Journal of Recent Sciences ISSN, 2277, 2502.

Shaffer, D., \& Kipp. K. (2013). Developmental Psychology: Childhood and Adolescence. Cengage Learning, 274-276.

Sharma, N., \& Vaid, S. (2005). Role of parents in the social development of adolescents: A comparison of low and middle socioeconomic status. Journal of Human Ecology, 18(2), 109-115. https://www.tandfonline.com/doi/abs/10.1080/09709274.2005.11905817.

Sheridan, R. (1976). Augmenting reading skills through language learning transfer. FLES Latin program evaluation reports, 1973-74, 1974-75, 1975-76.

Srivastava, P. S. (2016). Spiritual intelligence: An overview. International Journal of multidisciplinary research and development, 3(3), 224-227.

Sternberg, R. J. (2020). How mighty are the mitochondria in causing individual differences in intelligence? Some questions for David Geary. Journal of Intelligence, 8(1), 13. https:// doi.org/10.3390/jintelligence8010013.

Suud, F. M., Sutrisno, S., \& Madjid, A. (2019). Educational honesty: The main philosophical value in school. TARBIYA: Journal of Education in Muslim Society, 6(2), 141-154. http:// dx.doi.org/10.15408/tjems.v6i2.11769

Tüzer, H., Kırca, K., \& Özveren, H. (2020). Investigation of Nursing Students' Attitudes Towards Death and Their Perceptions of Spirituality and Spiritual Care. Journal of religion and health, 59(4), 2177-2190. https:// doi.org/10.1007/s10943-020-01004-9.

Waldo. A. D. (2014). Correlates of internet addiction among adolescents. Psychology, 1999. https:// doi.org/10.4236/psych.2014.518203

Wiley, P. D. (1985). High school foreign language study and college academic performance. Classical Outlook, 33-36.

Yu, M. (2017). Analysis on the construction of English classroom in colleges based on interactive teaching and multiple intelligence theory. DEStech 
Abdulwahid | Social Factor Effects on Linguistic Performance, Emotional and Spiritual Intelligence

Transactions on Social Science, Education, and Human Science, (icsste). https://doi.org/10.12783/dtssehs/icsste2017/9273.

Yunus, M. M., \& Salehi, H. (2012). The effectiveness of Facebook groups on teaching and improving writing: Students' perceptions. International journal of education and information Technologies, 1(6), 87-96.

Yusri, N. A., Kibtiyah, M., \& Hamim, T. (2020). Emotional intelligence with learning achievements reviewed from islamic education. International Journal of Islamic Educational Psychology, 1(2), 112-125. https:// doi.org/10.18196/ijiep.v1i2.9672.

Zamlut, S. Y. (2011). The relationship between arabic language proficiency, english language proficiency, and science academic achievement of 11th grade arabic speaking english language learners. (Publication no. 43) [Dissertations, Wayne State

University]. https://digitalcommons.wayne.edu/oa_dissertations/403

Zohar, D. (2012). Spiritual intelligence: The ultimate intelligence. Bloomsbury publishing. https://www.amazon.com/Spiritual-Intelligence-UltimateBloomsbury-Paperbacks/dp/0747536449. 